\title{
The Relationship Between High School Teachers' Perceptions of Organizational Culture and Motivation*
}

\author{
Rezzan Uçar ${ }^{1}$, Cemalettin İpek ${ }^{2}$ \\ ${ }^{1}$ Faculty of Education, Van Yüzüncü Yll University, Van, Turkey. \\ ${ }^{2}$ Faculty of Education, Kırşehir Ahi Evran University, Kırşehir, Turkey. \\ Correspondence: Rezzan Uçar, Faculty of Education, Van Yüzüncü Yıl University, Van, Turkey.
}

Received: April 8, 2019

Accepted: May 19, 2019 Online Published: May 22, 2019

doi:10.11114/jets.v7i7.4198

URL: https://doi.org/10.11114/jets.v7i7.4198

\begin{abstract}
The purpose of this research was to explore the relationship between school culture and motivation perceptions of teachers in high schools. The study tested whether the participant teachers' organizational culture and motivation perceptions were statistically different according to gender, marital status, school type and professional seniority and also it was attempted to determine whether the motivation perceptions of teachers could be statistically predicted from their organizational culture perceptions. A simple random sampling method was used in the study conducted with the teachers employed in high schools in Diyarbakır city center. The Organizational Culture Scale and the Teacher Motivation Scale were incorporated as data gathering instruments in the study. As a result of the research, it was concluded that the teachers' organizational culture perceptions statistically varied according to gender (in favor of the female teachers) and marital status (in favor of the married teachers) in the power culture dimension and according to professional seniority (in favor of those of 20 years or more teaching experience) in the support culture dimension and that the motivation perceptions of the teachers statistically varied according to gender (in favor of female teachers) in the external motivation dimension. In addition, it was found that the teachers' motivation perceptions could be statistically predicted from their organizational culture perceptions.
\end{abstract}

Keywords: organizational culture, teacher motivation, internal motivation, external motivation

\section{Introduction}

Each organization has different characteristics according to its area and purpose. Organizational culture is one of the major factors to shape these characteristics. Organizational culture is of great importance in terms of educational organizations. Achievements of educational organizations directly affect the future of society. On the other hand, the ability of educational organizations to meet society expectations is associated with organizational culture in schools because this culture enables us to understand and adopt goals in schools and to make common efforts to attain these goals. It also holds schools together with staff. What's more, it has a positive influence on employees' morale and productivity. In this context, it may be assumed that there is a relationship between organizational culture and motivation perceptions of teachers. When the related literature is reviewed, it is seen that there have been limited studies to examine the relationship between organizational culture and motivation perceptions of teachers. It is considered that this study, which examines the relation between these two concepts, will contribute to the literature.

\subsection{Organizational Culture}

Organizations seek for different ways of goal attainment, depending on the changes and developments in the social, cultural and economic structure of the society. One of these ways is to try to understand the social fabric of the organization and to change it when necessary. Organizational culture emerges as a combination of these social mechanisms in organizations. Especially since the 1980s, organizational culture has become an important aspect of organizational behavior and management concept.

\footnotetext{
*This research is an extension of the oral presentation at the 27th International Congress on Educational Sciences held in
} Antalya between 18 and 22 April 2018. 
The study of organizational culture by researchers in different disciplines such as anthropology, sociology, psychology, and management has led to the emergence of different definitions and views of the concept. According to Robbins (1994), organizational culture is a sequence of meanings shared by organizational members, which distinguishes the organization from other organizations. According to Hoy and Miskel (2010), organizational culture refers to a system of shared dispositions that holds units together and gives them a distinctive identity. According to Schein (1984), organizational culture is a model of the basic approaches that the group learns while solving problems of internal integration and external adaptation, works well enough to be effective, and is therefore shared with new members in order to teach them how to think, perceive and feel about these problems.

In the conducted studies on organizational culture, it is noteworthy that organizational culture is generally examined in four dimensions. For example, Hofstede (1980) suggests four different trends: cultural distance, masculinity/femininity, individuality and avoidance of uncertainty, while Harrison (1975) argues that there are four different ideological trends in organizations: power culture, role culture, task culture, and individual culture, Adapting these trends suggested by Harrison to the ancient Greek gods, Handy (1981) states that organizations have four different cultural characteristics, namely power culture (Zeus), role culture (Apollo) task culture (Athena) and individual culture (Dionisus). Based on the classifications by Harrison and Handy, Pheysey (1993) explains the cultural characteristics of organizations in four categories: power culture, role culture, success culture and support culture. In this study, Pheysey's (1993) classification of organizational culture was taken as a basis. Power culture; in such organizations, organizational rules are considered universal and are practiced for everyone. Status, obedience and supervision are attached importance. Role culture; activities of individuals in each position in the organization are pre-determined. Job descriptions, rules and principles determine the behavior of employees. Hierarchical decisions and non-personal relationships are taken as a basis. Success culture; organizations with such cultures are regarded as flexible bureaucracy. Upper management does not interfere with short-term decisions but determines the long-term policy. Decisions are made by committees. Support culture; mutual relations between the members of the organization, joint decision-making, and commitment are observed. Everyone in the organization sees themselves as organizational members and believes that they are valued (Pheysey, 1993).

Organizations are mini-communities with their own distinctive cultures and subcultures (Morgan, 1998). Therefore, each organizational culture reflects different characteristics. In this context, schools as educational organizations also have their own cultures (Özdemir, 2012). The concept culture in schools was first referred to the lifestyle by Waller (1932), who points out that schools have their own identity, with complex rituals of personal relationships and a range of traditions, irrational sanctions and ethical rules (Schoen \& Tedlie, 2008). In another definition, organizational culture in the school (school culture) is conceptualized as meaning patterns to include historically quoted norms, values, beliefs, traditions, and myths (Stolp \& Smith, 1995). In this respect, organizational culture in schools is considered as a lifestyle that occurs over time in schools (Balc1, 1996). Organizational culture in schools is influenced by the following factors: school age, historical development process, aims and objectives, socio-economic and geographical environment, socio-economic levels of students, rural and urban areas, facilities, technology used, school and class size, expectations of administrators, teachers, students and parents, and whether the education system is decentralized (Ipek, 1999).

Considering that the outcome of schools is man and people are taught in schools, school organizational behavior regulations have become more important than those in other organizations (Doğan, 2017), and this increases the significance of organizational culture in schools. Organizational culture in educational institutions includes values, symbols, beliefs and shared meanings of parents, students, teachers, and others who are designed as a group or community, and manages what is valuable for the group, and how members should think, feel and act (Sergiovanni, 1984). Therefore, it restricts member activities, but also provides harmony and adaptation, contributes to the comfort of employees by removing task ambiguities, and as a result of generationally transmitted shared behaviors, brings compatibility between organizational members and between organizations and the external environment, and increases motivation by establishing a psychological bond between staff and organizations (Çelik, 2007). In this context, cultures that enable their members to participate in various organizational processes and to feel organizational commitment are also called powerful cultures (Murat \& Açıkgöz, 2007). A strong organizational culture is a prerequisite for an effective school. On the other hand, culture itself could be a problem in some schools. In schools with not-very-strong cultures, bonds and communication between administrators, teachers, students and parents are weak, all members have low achievement expectation levels for each other, feelings of suspicion and hostility among members are common, destructive conflicts are frequent, and feelings of love and respect are poor among members and motivation is low (Ozdemir, 2006). Thus, organizational culture in schools gains importance as one of the basic factors that influences and directs the behaviors of teachers and as a significant aspect of their motivation.

\subsection{Teacher Motivation}

Derived from the root of "movere" which means "to move" in Latin, (Ramlall, 2004; Steers, Porter \& Bigley, 1996), 
motivation, in the most general term, is defined as driving force (stimulation, desire, impulse, and so on) that leads an organism to a particular object or situation or a process that initiates, sustains and directs spiritual or physical activity (Budak, 2005) and is thought to be a dynamic set of factors that describes individual behavior (Chişiu, 2013), including desires, wishes, needs, impulses (hunger, thirst, sexuality, etc.) and interests (Cüceloğlu, 1999).

Motivation affects individual enthusiasm and productivity (Thahier, Ridjal \& Risani, 2014). Positively motivated employees work hard to achieve their goals and thus, enjoy what they do. Performance of less motivated employees decline and they compromise on service quality (Kasenga \& Hurtig, 2014).

People can get not only motivated to different extents, but also in different ways. Research has emphasized that individual performance and experience could vary according to internal or external reasons (Amabile, 1997; Ryan \& Deci, 2000). Internal motivation is solely associated with task performance. Arising from task content, internal motivation includes factors such as interesting and challenging work, self-management and responsibility, diversity, creativity, opportunities to use skills and abilities, and sufficient feedback on the satisfaction of endeavors (Mottaz, 1985). External motivation is individual influence by administrators, communities, people are part of or various external factors in order to achieve task goals with the use of a number of methods (Başaran, 2004). External motivation is based on punishment and rewards. Fruitful outcomes are more important than the act itself. It approaches motivation from a behavioral perspective. It causes individuals to act on incentives and disincentives (Hoy \& Miskel, 2010). The following have been three constant elements of educational organizations from past to present: teachers, students and curricula. Still considered as basic part of education, teachers (Şimşek, 2010) play a major role in teaching and contribute greatly to the education system despite all the possibilities provided by scientific and technological developments.

Teaching is instinctively magnificent, and it is pleasurable for teachers to see that learners are doing well thanks to the quality of their teaching. However, despite being admirable, education provided by a teacher, competence or teaching cannot simply last forever by itself (Senge, Cambron-McCabe, Lucas, Smith, Dutton \& Kleiner, 2014). In this context, success of schools and goal attainment might depend on the willingness of employed teachers, in other words, teacher motivation.

Teacher motivation involves internal values associated with teaching and preference to continue teaching and teaching efforts that are affected by a range of environmental factors (Han \& Yin, 2016). In this context, internal and external sources of motivation are important in teacher motivation (Yazıc1, 2009). An internally motivated teacher carries out duties for the love of teaching, job satisfaction, and the feeling of accomplishment and self-fulfillment whereas an externally motivated teacher fulfills duties for certain rewards (Wu, 2012, 2015) like salary or as a result of social support by administrators, students and parents and encouragements (Yazic1, 2009).

Today, a teacher plays the following roles: a teacher to show children real life, an educator to provide children with particular information and knowledge accumulation, a mainstreamer to get schools, families, and environment together, a socializer to get children ready for society life and a trainer (Can, 2013) and occasionally a teacher has to have roles as a parent, sometimes a police officer, or sometimes a caregiver, which are all out of educational context. What's more, all these roles are carried out with great mastery, expertise and wisdom, while paying attention to the interests, needs and differences of children (Saban, 2002). In this sense, teachers' job satisfaction and encouragement and thus love of teaching are crucial in that all these factors entail high quality individuals taught by those teachers.

\subsection{The Relationship between Organizational Culture and Teacher Motivation}

Each school has its own character or feeling. This can be felt when approaching a school building. It is likely to see this character through the doors, on the pictures on the walls and in the students in the halls. This character may be understood from teacher-student interaction in the classroom and student-student communication on the playground. Organizational culture in schools, which reflects the character of a school, long-established values, beliefs and tradition patterns throughout its history (Deal \& Peterson, 1990), influences and shapes thoughts and feelings of teachers, students and administrators. Teachers might have different expectations and values. Work motivation of teachers is considered to be one of those (Demirtaş, 2010).

Motivated employees are enthusiastic about their work and therefore feel responsible for the success of the institution they are working for (Sokro, 2012). Culture informs teachers about issues such as what a teacher means, what teaching methods are available and approved for use, and what is appropriate or inappropriate for students. Culture provokes teachers' energy to fulfill tasks, and to feel loyalty and commitment shaped by organization and ideals (Owens, 1987).

In successful schools, culture serves as a compass to direct people in a common direction, provides a set of norms that defines what people need to accomplish and has a particular meaning and significance for teachers, administrators and students (Sergiovanni, 1984). Teachers constitute the basis of student motivation through the quality of teaching and the 
development of teacher-student relationship, and they are in a very important position in the implementation of educational policies, as well as important roles in the class. In this context, teacher motivation is important because it affects both organizations and individuals and has an effect on classrooms and schools (Viseu, Jesus, Rus, Canavarro \& Pereirra, 2016). Motivated teachers are more likely to work for educational progress and innovative legislation. In this context, teacher motivation is also considered to be an important factor for class effectiveness and school development (Wu, 2015). Besides, teacher motivation is significant in terms of teachers' personal fulfillment and satisfaction (Jesus \& Lens, 2005).

The relationship between organizational culture and motivation has been a research subject in many fields such as strategic management, organizational behavior, and industrial organizations (Parthasaraty \& Ramalingam, 2015). Research has shown that there are relationships between organizational culture of the schools and school effectiveness (Ayık \& Ada, 2009), student academic achievement (Demirtaş, 2010; Vislocky, 2005), academic optimism (Yilmaz \& Kurşun, 2015), organizational health (Özdemir, 2012), learning organization (Ayık \& Şayir, 2015), job satisfaction (Gligorovic, Nikolic, Terek, Glusac \& Tasıc), leadership practices (Turan \& Bektaş, 2013), academic leadership (Şahin, 2011), and teacher leadership (Yusof, Osman \& Noor, 2016), and it was also found that teachers' positive perceptions of organizational culture increased their motivation levels (Aelterman, Engels, Petegem, \& Verhaeghe, 2007; Cevik \& Köse, 2017; Sertel, 2016; Yilmaz, 2009). Teacher motivation, on the other hand, was found to have a significant effect on the motivation and academic achievement of students (Atkinson, 2000; Carey, 2004; Hattie, 2013; Haycock, 1998). In this context, students need motivated teachers; and teachers need opportunities that provide motivational potential (Remijan, 2014). Thus, the relationship between organizational culture and motivation perceptions of teachers is important for the effectiveness of learning process in schools.

When the related literature is reviewed, it is seen that there are only a small number of postgraduate theses examining the relationship between employee motivation and organizational culture in Turkey (Karaoğlu 2014; Sop, 2016; Sözer, 2006). One of these studies was conducted with the employees of public institutions (Sözer, 2006), another with accommodation sector (hotel) staff (Karaoğlu, 2014) and the other with university employees (Sop, 2016). In the literature, it is observed that the number of research carried out besides the theses on this subject is not very high (Alayoğlu \& Doğan, 2015; Kavi, 2011; Yenihan, 2015) and only two of a few studies on the relationship between organizational culture and motivation have been conducted in higher education institutions, and that one was conducted with university employees (Sop, 2016), and the other with university students (Yenihan, 2015). Therefore, it is understood in the literature that the number of research on the relationship between organizational culture and motivation perceptions of teachers is rather limited (Çevik \& Köse, 2017). From this perspective, it is expected that the research to examine the relationship between organizational culture and motivation perceptions of teachers employed in secondary education institutions will contribute to the related literature.

\subsection{The Purpose of the Study}

In this study, it was aimed to explore the relationship between organizational culture and motivation perceptions of teachers working in secondary education institutions. Within the context of this aim, the answers to the following research questions were sought:

1) What are teachers' perceptions of organizational culture and motivation?

2) Do teacher perceptions of organizational culture and motivation statistically vary according to gender, marital status, school type and professional seniority?

3) Do teacher perceptions of organizational culture predict their motivation perceptions?

\section{Method}

Information on the population, sample, data gathering instruments, and data analysis process of the research which was carried out using a relational screening model are given under the subheadings below.

\subsection{Research Population and Sample}

This research was conducted with the teachers employed in secondary schools in the following central districts of Diyarbakir province; Bağlar, Kayapınar, Sur and Yenişehir. Bearing the difficulty of reaching all the teachers in the population in mind, 25 teachers from a total of 20 schools selected by simple random sampling were determined, consisting of five secondary schools from each district chosen by simple random sampling method again in order to represent the research population by district and a total of 500 teachers were reached. From 462 measurement tools that gave feedback, 443 forms filled according to the instructions were evaluated. 166 of the teachers who participated in the research were female and 277 were male. 337 participants were married, and 106 participants were single. 280 of the participants were working in general high schools and 163 in vocational and technical high schools. Professional seniority of teachers ranged from 2 months to 34 years. 


\subsection{Data Gathering Instruments}

The "Organizational Culture Scale" developed by İpek (1999) and the "Teacher Motivation Scale" developed by Uçar (2015) were incorporated as data gathering instruments in the research.

The "Organizational Culture Scale" was developed by İpek (1999), based on Pheysey's (1993) organizational culture classification. The scale consisted of 36 items, and the following four dimensions: the power culture, the role culture, the achievement culture and the support culture. It was concluded that the factor loadings of the items in the power culture dimension ranged from .32 to .72 and the explained variance was $31 \%$; the factor loadings of the items in the role culture dimension ranged from .26 to .76 , and the explained variance was $30 \%$; the factor loadings of the items in the achievement culture dimension ranged from .38 to .72, and the explained variance was $35 \%$; the factor loadings of the items in the support culture dimension ranged from .45 to .82 , and the explained variance was $53 \%$. The Cronbach's alpha coefficient was checked for the reliability of the scale. The Cronbach's alpha coefficient was $\alpha=.60$ in the original scale for the power culture, and it was found $\alpha=.69$ for the role culture, $\alpha=.78$ for the achievement culture and $\alpha=.90$ for the support culture. In this research, the Cronbach's alpha coefficients were calculated as follows: $\alpha=.78$ for the power culture, $\alpha=.82$ for the role culture, $\alpha=.90$ for the achievement culture and $\alpha=.92$ for the support culture.

The "Teacher Motivation Scale", developed by Uçar (2015) consisted of 19 items and two dimensions: internal and external motivation. It was concluded that the factor loadings of the items in the internal motivation dimension ranged from .53 to .80 and the explained variance was $30 \%$; the factor loadings of the items in the external motivation dimension ranged from .61 to .87 , and the explained variance was $23 \%$. The total explained variance of the "Teacher Motivation Scale" was found $53.22 \%$. As a result of the confirmatory factor analysis for the scale, the model fit was calculated as $\chi 2=335.08 ; \mathrm{df}=150 ;(\chi 2 / \mathrm{df})=2.23 ; 0.96$ for CFI; 0.85 for GFI ; 0.069 for SRMR; 0.078 for RMSEA and 0.95 for NNFI. The Cronbach's alpha of the original scale was $\alpha=.86$ for internal motivation and $\alpha=.91$ for external motivation. In the study, the Cronbach's alpha values were found as follows: $\alpha=.85$ for internal motivation and $\alpha=.91$ for external motivation.

Since the validity analyses were carried out on the scales by the researchers who developed the scales (İpek, 1999; Uçar, 2015), there was no need to perform validity analysis again.

\subsection{Data Analysis}

During the data analysis process on SPSS program, arithmetic mean and standard deviation were employed to define the participant teachers' perceptions of the dimensions of the organizational culture scale and the teacher motivation scale. Prior to the difference test application, the following were examined: a normal data distribution, skewness and kurtosis values, Q-Q graphics (Q-Q Plot) and histogram graphics. As a result of the conducted analysis, the skewness values of the variables ranged from -,21 to $-1,25$ while the kurtosis values ranged from 1,29 to ,01. When Skewness and kurtosis values range from $-1,5$ to $+1,5$, distributions are considered to be normal (Tabachnick and Fidell, 2013). Q-Q and histogram graphics also showed that the distribution of the variables met the assumption of normality (Can, 2014). In this context, $t$ test, a parametric test, and one-way variance analysis were employed in order to explore whether the teachers' perceptions of organizational culture and teacher motivation varied according to gender, marital status, type of school and professional experience. The existence of a suspicion of auto-correlation, as well as the normal distribution of the data, was examined in order to understand the suitability of the research data for regression analysis. If we suspect auto-correlation, then Durbin Watson analysis is employed to test it. The closer the Durbin-Watson value to 2, the more the auto-correlation suspicion disappears for multiple linear regression models (Doğan and Y1lmaz, 2017). In the study, the Durbin-Watson values were found 1,96 and 1,86, which could be interpreted as there was no auto-correlation. The values of VIF (Variance Inflation Factor) and tolerance for the independent variables were also examined in the study to determine the degree of multiple correlation for the predictive variables and it was concluded that the VIF values ranged from 1,81 to 2,92 and the tolerance values were higher than 0,2 . When the VIF value is lower than 10 and the tolerance value is higher than 0,2, then the suspicion of multiple correlation disappears (Can, 2014). All the analyses showed that the data set was suitable for regression analysis. To this end, multiple regression analysis was used to determine whether the teachers' motivation could be predicted from their organizational culture perceptions.

\section{Findings}

In this section, the findings of the study are presented. In this context, teachers' perception of organizational culture comprising power, role, achievement and support culture sub-dimensions and their motivational perceptions in terms of internal and external motivation sub-dimensions were described. Moreover, organizational culture and motivation perceptions of teachers were compared according to gender, marital status, school type and professional seniority. Finally, teachers' internal and external motivations perceptions were tried to be predicted from their perceptions of the organizational culture sub-dimensions. 
The descriptive findings in terms of teacher perceptions of organization culture and motivation are presented in Table 1 within the context of sub-dimensions.

Table 1. Mean and Standard Deviation Scores for Organizational Culture and Teacher Motivation Perceptions in Terms of Sub-Dimensions

\begin{tabular}{lllccl}
\hline Scale & Sub-Dimensions & $\mathbf{n}$ & $\bar{X}$ & sd & Agreement Range \\
\hline \multirow{3}{*}{ Organizational culture } & Power culture & 443 & 3,37 &, 752 & Little appropriate \\
& Role culture & 443 & 3,37 &, 670 & Little appropriate \\
& Achievement culture & 443 & 3,32 &, 816 & Little appropriate \\
& Support culture & 443 & 3,48 &, 882 & Quite appropriate \\
\hline \multirow{2}{*}{ Teacher Motivation } & Internal Motivation & 443 & 3,64 &, 744 & Mostly agree \\
& External Motivation & 443 & 4,34 &, 661 & Totally agree
\end{tabular}

In Table 1, the arithmetic means reflecting organizational culture perceptions of the teachers were found 3,37 in the power culture and role culture sub-dimensions; 3,32 in achievement culture and 3,48 in support culture sub-dimensions. The participant teachers agreed with the internal motivation dimension of teacher motivation by 3.64 and with the external motivation dimension by 4.34 .

The means of teacher perceptions of organizational culture and the motivation levels are compared according to gender in Table 2.

Table 2. Comparison of Teacher Perceptions of Organizational Culture and Motivation According to Gender

\begin{tabular}{|c|c|c|c|c|c|c|c|}
\hline Scale & Dimension & Gender & $\mathbf{n}$ & $\bar{X}$ & Sd & $\mathbf{t}$ & $\mathbf{p}$ \\
\hline \multirow{8}{*}{ Organizational culture } & \multirow{2}{*}{ Power culture } & Female & 166 & 3,46 & ,798 & \multirow{2}{*}{2,031} & \multirow{2}{*}{, 043} \\
\hline & & Male & 277 & 3,31 & ,717 & & \\
\hline & \multirow{2}{*}{ Role culture } & Female & 166 & 3,41 & 660 & \multirow{2}{*}{1,107} & \multirow{2}{*}{,269 } \\
\hline & & Male & 277 & 3,34 & 674 & & \\
\hline & \multirow{2}{*}{ Success culture } & Female & 166 & 3,32 & 867 & \multirow{2}{*}{, 018} & \multirow{2}{*}{,986 } \\
\hline & & Male & 277 & 3,32 & ,785 & & \\
\hline & \multirow{2}{*}{ Support culture } & Female & 166 & 3,53 & ,901 & \multirow{2}{*}{,891 } & \multirow{2}{*}{, 373} \\
\hline & & Male & 277 & 3,46 & 870 & & \\
\hline \multirow{4}{*}{ Teacher motivation } & \multirow{2}{*}{ External Motivation } & Female & 166 & 4,44 & ,623 & \multirow{2}{*}{2,677} & \multirow{2}{*}{, 008} \\
\hline & & Male & 277 & 4,27 & ,675 & & \\
\hline & \multirow{2}{*}{ Internal Motivation } & Female & 166 & 3,68 & ,715 & \multirow{2}{*}{, 544} & \multirow{2}{*}{, 587} \\
\hline & & Male & 277 & 3,64 & ,761 & & \\
\hline
\end{tabular}

When Table 2 is examined, it is seen that the teachers' perceptions of organizational culture do not significantly vary according to gender in the role, success, support culture dimensions but they significantly vary in the power culture dimension $(\mathrm{t}=2,031 ; \mathrm{p}=, 043)$. It is accordingly understood that the female teachers perceive a power culture tendency at a higher level than the male teachers in schools they work for. The teacher motivation perceptions do not vary according to internal motivation at a statistically significant level. However, there is a significant difference in the external motivation dimension. The external motivation perceptions of the female teachers were found to be statistically higher than those of the male teachers $(t=2,677 ; p=, 008)$.

The means of teacher perceptions of organizational culture and motivation according to marital status are given in Table 3. 
Table 3. T-Test Results of Teacher Perceptions of Organizational Culture and Motivation According to Marital Status

\begin{tabular}{|c|c|c|c|c|c|c|c|}
\hline Scale & Dimension & Status & $\mathbf{n}$ & $\bar{X}$ & Sd & $\mathbf{t}$ & $\mathbf{p}$ \\
\hline \multirow{8}{*}{ Organizational culture } & \multirow{2}{*}{ Power culture } & Married & 337 & 3,41 & ,739 & \multirow{2}{*}{2,233} & \multirow{2}{*}{,026 } \\
\hline & & Single & 106 & 3,23 & ,774 & & \\
\hline & \multirow{2}{*}{ Role culture } & Married & 337 & 3,39 & ,646 & \multirow{2}{*}{1,316} & \multirow{2}{*}{,189 } \\
\hline & & Single & 106 & 3,29 & ,737 & & \\
\hline & \multirow{2}{*}{ Success culture } & Married & 337 & 3,33 & ,798 & \multirow{2}{*}{,393 } & \multirow{2}{*}{,694 } \\
\hline & & Single & 106 & 3,30 &, 872 & & \\
\hline & \multirow{2}{*}{ Support culture } & Married & 337 & 3,51 &, 843 & \multirow{2}{*}{1,099} & \multirow{2}{*}{,273 } \\
\hline & & Single & 106 & 3,40 & ,992 & & \\
\hline \multirow{4}{*}{ Teacher motivation } & \multirow{2}{*}{ External motivation } & Married & 337 & 4,34 & ,671 & \multirow{2}{*}{,306 } & \multirow{2}{*}{, 760} \\
\hline & & Single & 106 & 4,32 & ,629 & & \\
\hline & \multirow{2}{*}{ Internal motivation } & Married & 337 & 3,68 & ,744 & \multirow{2}{*}{,924 } & \multirow{2}{*}{, 356} \\
\hline & & Single & 106 & 3,60 & ,740 & & \\
\hline
\end{tabular}

In Table 3, it is seen that the teachers' perceptions of organizational culture do not statistically vary in the role, success and support culture dimensions according to marital status, but significantly vary in the power culture dimension. It is understood that the married teachers have higher power culture perceptions than the single ones. The teachers' motivation perceptions do not significantly vary in the external and internal motivation dimensions according to marital status.

The means of the teachers' perceptions of organizational culture and the motivation perceptions according to school type are given in Table 4.

Table 4. T-Test Results of Teacher Perceptions of Organizational Culture and Motivation According to School Type

\begin{tabular}{|c|c|c|c|c|c|c|c|}
\hline Scale & Dimension & Type & $\mathbf{n}$ & $\bar{X}$ & Sd & $\mathbf{t}$ & $\mathbf{p}$ \\
\hline \multirow{8}{*}{ Organizational culture } & \multirow{2}{*}{ Power culture } & General & 280 & 3,44 & ,707 & \multirow{2}{*}{2,636} & \multirow{2}{*}{,009 } \\
\hline & & Vocational & 163 & 3,24 &, 810 & & \\
\hline & \multirow{2}{*}{ Role culture } & General & 280 & 3,45 & ,636 & \multirow{2}{*}{3,308} & \multirow{2}{*}{,001 } \\
\hline & & Vocational & 163 & 3,23 & ,704 & & \\
\hline & \multirow{2}{*}{ Success culture } & General & 280 & 3,42 & ,791 & \multirow{2}{*}{3,305} & \multirow{2}{*}{,001 } \\
\hline & & Vocational & 163 & 3,16 & ,833 & & \\
\hline & \multirow{2}{*}{ Support culture } & General & 280 & 3,62 & ,817 & \multirow{2}{*}{4,192} & \multirow{2}{*}{, 000} \\
\hline & & Vocational & 163 & 3,26 & ,942 & & \\
\hline \multirow{4}{*}{ Teacher motivation } & \multirow{2}{*}{ External motivation } & General & 280 & 4,36 & ,641 & \multirow{2}{*}{, 831} & \multirow{2}{*}{,406 } \\
\hline & & Vocational & 163 & 4,30 & ,694 & & \\
\hline & \multirow{2}{*}{ Internal motivation } & General & 280 & 3,70 &, 730 & \multirow{2}{*}{1,341} & \multirow{2}{*}{, 180} \\
\hline & & Vocational & 163 & 3,60 & ,764 & & \\
\hline
\end{tabular}

According to Table 4, the teachers' perceptions of organizational culture significantly vary according to school type in the power, role, success and support culture dimensions. It is understood that the perceptions of the teachers employed in general high schools in all the dimensions are higher than those of the teachers employed in vocational and technical high schools. It is seen that the teachers' motivation perceptions do not significantly vary in the external and internal motivational dimensions according to school type.

The means of teacher perceptions of organizational culture and motivation of professional seniority are presented in Table 5. 
Table 5. Results of Anova Test on Teachers' Perceptions of Organizational Culture and Motivation According to Professional Seniority

\begin{tabular}{|c|c|c|c|c|c|c|c|c|c|}
\hline Scale & Dimension & Seniority & $\mathbf{n}$ & $X$ & sd & $\mathbf{F}$ & df & $\mathbf{p}$ & Difference \\
\hline \multirow{20}{*}{ 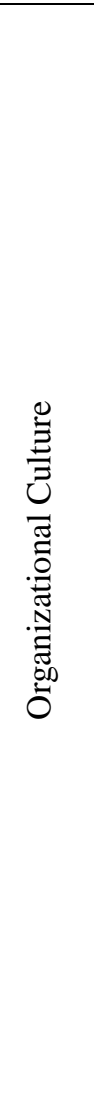 } & \multirow{5}{*}{ Power culture } & 7/less & 106 & 3,36 &, 730 & \multirow{5}{*}{,686 } & \multirow{5}{*}{439} & \multirow{5}{*}{,303 } & \\
\hline & & $8-13$ & 109 & 3,45 &, 743 & & & & \\
\hline & & $14-19$ & 116 & 3,26 & ,708 & & & & \\
\hline & & 20/more & 112 & 3,40 &, 817 & & & & \\
\hline & & Total & 443 & 3,37 &, 751 & & & & \\
\hline & \multirow{5}{*}{ Role culture } & 7/less & 106 & 3,67 & ,668 & \multirow{5}{*}{, 112} & \multirow{5}{*}{439} & \multirow{5}{*}{,863 } & \\
\hline & & $8-13$ & 109 & 3,62 & ,699 & & & & \\
\hline & & $14-19$ & 116 & 3,60 & ,945 & & & & \\
\hline & & 20/more & 112 & 3,76 & ,672 & & & & \\
\hline & & Total & 443 & 3,66 & ,669 & & & & \\
\hline & \multirow{5}{*}{ Success culture } & 7/less & 106 & 3,28 &, 795 & \multirow{5}{*}{,957 } & \multirow{5}{*}{439} & \multirow{5}{*}{,230 } & \\
\hline & & $8-13$ & 109 & 3,26 &, 834 & & & & \\
\hline & & $14-19$ & 116 & 3,29 & ,798 & & & & \\
\hline & & $20 /$ more & 112 & 3,46 &, 829 & & & & \\
\hline & & Total & 443 & 3,32 & ,816 & & & & \\
\hline & \multirow{5}{*}{ Support culture } & 7/less & 106 & 3,32 & ,960 & \multirow{5}{*}{3,108} & \multirow{5}{*}{439} & \multirow{5}{*}{,007 } & \multirow{5}{*}{$\begin{array}{l}\text { 7/less } \\
\text { 20/more }\end{array}$} \\
\hline & & $8-13$ & 109 & 3,43 & ,894 & & & & \\
\hline & & $14-19$ & 116 & 3,45 & ,797 & & & & \\
\hline & & 20/more & 112 & 3,72 & ,838 & & & & \\
\hline & & Total & 443 & 3,48 & ,881 & & & & \\
\hline \multirow{10}{*}{ 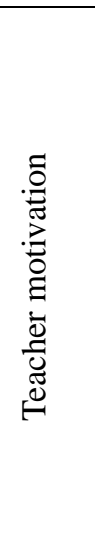 } & \multirow{5}{*}{$\begin{array}{l}\text { External } \\
\text { Motivation }\end{array}$} & 7/less & 106 & 4,34 &, 621 & \multirow{5}{*}{, 031} & \multirow{5}{*}{439} & \multirow{5}{*}{,993 } & \\
\hline & & $8-13$ & 109 & 4,32 & ,666 & & & & \\
\hline & & $14-19$ & 116 & 4,35 & ,630 & & & & \\
\hline & & 20/more & 112 & 4,34 & ,728 & & & & \\
\hline & & Total & 443 & 4,34 & ,661 & & & & \\
\hline & \multirow{5}{*}{$\begin{array}{l}\text { Internal } \\
\text { Motivation }\end{array}$} & 7/less & 106 & 3,67 &, 703 & \multirow{5}{*}{1,030} & \multirow{5}{*}{439} & \multirow{5}{*}{,379 } & \\
\hline & & $8-13$ & 109 & 3,62 &, 725 & & & & \\
\hline & & $14-19$ & 116 & 3,60 & 692 & & & & \\
\hline & & $20 /$ more & 112 & 3,76 &, 842 & & & & \\
\hline & & Total & 443 & 3,66 &, 734 & & & & \\
\hline
\end{tabular}

As seen in Table 5, the teachers' perceptions of organizational culture do not significantly vary in the power, role and success culture dimensions according to professional seniority. They significantly vary in the support culture dimension. It is understood that the perceptions of those who have 20 years or more of teaching experience are higher than the perceptions of the teachers who have 7 years or less of teaching experience. The external and internal motivation perceptions of the teachers do not significantly vary according to professional seniority.

External motivation of the teachers employed in secondary schools was attempted to be predicted from their organizational culture perceptions and the regression analysis results conducted for this purpose are presented in Table 6. 
Table 6. Results of Regression Analysis for Prediction of Teachers' External Motivation Perceptions from Organizational Culture Dimensions

\begin{tabular}{|c|c|c|c|c|c|c|c|}
\hline Variable & B & $\begin{array}{l}\text { Standard } \\
\text { error of } \\
\text { the mean }\end{array}$ & B & $\mathbf{t}$ & $\mathbf{P}$ & Binary $\mathbf{r}$ & Partial $\mathbf{r}$ \\
\hline Constant & 3,751 &, 171 & & 21,901 & ,000 & & \\
\hline Power culture &,- 016 &, 056 &,- 019 & ,293 &, 769 &, 10 &,- 01 \\
\hline Role culture &, 105 &, 068 & ,106 & 1,543 &, 123 &, 15 &, 07 \\
\hline Success culture &,- 049 &, 065 &,- 060 &, 747 & ,456 & ,13 &,- 04 \\
\hline Support culture &, 130 &, 056 &, 173 &, 173 &, $021^{*}$ & ,18 &, 11 \\
\hline $\mathrm{R}=, 19$ & & & & & & & \\
\hline $\mathrm{F}_{(4,438)}=4,16$ & & & & & & & \\
\hline
\end{tabular}

When Table 6 is examined, it is seen that the external motivation perceptions of the teachers can be predicted at a statistically significant level from organizational culture perceptions $(\mathrm{R}=.19, \mathrm{~F}=4.16, \mathrm{p}=.003)$. According to the regression analysis results, it is understood that the teachers' power, role, success and support culture perceptions only explain $4 \%$ of the variance at the level of external motivation. When the correlation between the external motivation perceptions of the teachers and the perceptions of the organizational culture, power, role, success and support cultures are examined together, it is observed that there is .10 correlation with power culture, .15 with role culture and .13 with support culture. When the correlation between the organizational culture dimensions and the external motivation perceptions of the teachers are independently examined, it is seen that the correlation is $-.10(\mathrm{p}=.769)$ with power culture, $.07(\mathrm{p}=.123)$ with role culture, $-.04(\mathrm{p}=.456)$ with success culture and $.11(\mathrm{p}=.021)$ with support culture. According to the standardized regression coefficient, the relative order of significance of the predictor dimensions on external motivation is as follows: support culture, role culture, success culture and power culture. When the t-test results of the significance of the regression coefficients are examined, it is seen that only the "support culture" sub-dimension is an important predictor of external motivation. On the other hand, the subscales of power, role and success culture do not have a significant influence on the teachers' external motivation perceptions.

The internal motivation perceptions of the teachers were attempted to be predicted from the perceptions of organizational culture and therefore, the results of regression analysis performed for this purpose are given in Table 7.

Table 7. Results of Regression Analysis for Prediction of Teachers' Internal Motivation Perceptions from Organizational Culture Dimensions

\begin{tabular}{llllllll}
\hline Variable & B & $\begin{array}{l}\text { Standard } \\
\text { Error of } \\
\text { the Mean }\end{array}$ & B & t & $\mathbf{p}$ & Binary r & Partial r \\
\hline Constant & 1,999 &, 176 & & 11,385 &, 000 & & \\
Power culture &, 094 &, 057 &, 095 & 1,657 &, 098 &, 32 &, 07 \\
Role culture &, 085 &, 069 &, 077 & 1,227 &, 221 &, 34 &, 05 \\
Success culture &, 211 &, 067 &, 231 & 3,163 &, $002 *$ &, 42 &, 14 \\
Support culture &, 102 &, 057 &, 121 & 1,772 &, 077 &, 38 &, 08 \\
\hline $\mathrm{R}=, 45$ & $\mathrm{R}$ & & & & & \\
$\mathrm{F}_{(4,438)}=27,37$ & $\mathrm{p}=, 000$ & & & & & &
\end{tabular}

In Table 7, it is clear that the internal motivation perceptions of the teachers employed in secondary education institutions can be predicted at a statistically significant level from the perceptions of power, role, success and support culture $(\mathrm{R}=45 ; \mathrm{F}=27,37 ; \mathrm{p}=.000)$. When the regression analysis results are taken into consideration, it is understood that the teachers' perceptions of power, role, success and support culture explain $20 \%$ of the variance in the internal motivation perceptions. When the correlations between the teachers' internal motivation perceptions and the organizational culture dimensions are examined together, the correlation between internal motivation and the power culture dimension is found ,32; the correlation between internal motivation and the role culture dimension is found ,34; the correlation between internal motivation and success culture is found, 42 and the correlation between internal 
motivation and support culture is found ,38. When the correlation between the organizational culture dimensions and internal motivation are independently examined, the correlation between power culture and internal motivation is found ,07 ( $p=098)$; the correlation between role culture and internal motivation is found ,05 ( $p=, 221)$; the correlation between success culture and internal motivation is found ,14 $(\mathrm{p}=002)$ and the correlation between support culture and internal motivation is found, $08(\mathrm{p}=, 077)$. According to the standardized regression coefficient, the relative order of significance of the predictor dimensions on internal motivation is as follows: success culture, support culture, power culture and role culture. When the results of the t-test on the significance of the regression coefficients are examined, it is seen that only the success culture sub-dimension $(r=, 42 ; \mathrm{p}=, 002)$ is an important predictor of internal motivation. However, power culture, role culture and support culture do not have a significant influence.

\section{Result, Discussion and Recommendations}

As a result of the research, the teachers employed in secondary education institutions assessed the power, role and success culture dimensions of organizational culture as little appropriate, whereas they assessed the support culture dimension as quite appropriate. This result can be interpreted as follows: they think that their schools tend to be more of a support culture. In other words, it may be argued that an organizational culture in which mutual relations, interaction, cooperation, trust and involvement in decision making process are attached importance is more welcomed by teachers. In support culture, informal structure is more important than formal structure (İpek, 2012). The fact that more informal structure takes place in schools and that the influence factor has become more important than authority (Bursalığlu, 2000) may have caused the teachers to perceive support culture the most. There are studies in the literature that support the research findings. In a study by Balay, Kaya and Cülha (2013), the participant teachers perceived support culture the most and in studies by Şahin (2017), Sabancı, Şahin, Sönmez and Yılmaz (2017), the participant administrators and teachers perceived support culture the most. In the research conducted by İpek (2012), Şimşek and Babaoğlan (2015), the teachers agreed with contemporary school culture covering support culture more. Similarly, in their research, Firat (2007) and Irmak (2017) also found the school principals and the teachers agreed with the integration and sense of belonging dimensions with similar characteristics to support culture the most. In Çetin, Doğan and Kınık's (2016) study with university students, the students' support culture perceptions were found higher. In Özdere's (2018) study, the instructors perceived support culture the most. On the other hand, in some studies (Tanrı̈ğen, Baştürk \& Başer, 2014; Yaprak Kaya, 2015), the teachers stated that their schools tended to have task culture the most.

There was no significant difference observed between the perceptions of the male and female teachers in the role, success and support culture sub-dimensions of organizational culture in schools. However, the female teachers agreed with the power culture dimension more than the male ones. In the light of this finding, it may be suggested that female teachers see culture in their schools more rigid and supervisory. Sabancı, Şahin, Sönmez and Yılmaz (2017) also reached similar findings in their study. İpek (2012) concluded that the female teachers agreed with the traditional organizational culture covering power culture more than the male teachers. In a study by Terzi (2005), the female teachers agreed with bureaucratic culture with similar characteristics to power culture more than the male teachers. On the other hand, in some studies (Irmak, 2017; Sahin, 2017) no significant difference was found in the organizational culture perceptions of the participant teachers according to gender.

The teachers' organizational culture perceptions showed a statistically significant difference in the power culture sub-dimension according to marital status. Accordingly, the married teachers thought their schools had a power culture tendency more than the single ones. It might have been caused by the fact that power culture in school is felt more by married teachers as they need to have a balance between their duties at school and private life responsibilities because of their different responsibilities outside work.

In the study, the perceptions of power, role, success and support culture of those employed in general high schools were found statistically higher than the perceptions of the teachers employed in vocational and technical high schools. It is unlikely that culture that has a strong influence on organizational success has a stereotype (Parthasarathy \& Ramalingam, 2015). In this context, more than one school culture may have been perceived in general high school. Therefore, it can be suggested that the teachers employed in general high schools perceived all the organizational culture dimensions more than those employed in vocational and technical high schools. Unlike these results, İpek (2012) concluded that the teachers employed in vocational high schools had higher perceptions of traditional organizational culture than those in general high schools.

One of the findings of the research is that the support culture perceptions of the participant teachers increased as professional seniority increased. In this context, it was concluded that those with 20 or more years of seniority had statistically higher levels of support culture perceptions than those of the teachers with 7 or less years of seniority. In studies by İpek (2012) and Firat (2007), it was also concluded that the teacher perceptions of organizational culture in schools increased as seniority increased. In this case, it can be argued that teachers perceive organizational culture more 
in terms of cooperation, communication, joint decision-making regarding education and training practices as the term of employment increases.

It was determined that the motivation perceptions of the teachers employed in secondary schools were high. The teachers' external motivation perceptions were higher than their internal motivation perceptions. This situation might be interpreted as the fact that teachers are more influenced by given rewards and punishments, and also by social support and encouragement they receive from administrators, students and parents (Wu, 2003). Because in externally motivated behaviors, actions are taken to achieve a result such as winning prizes or avoiding negative consequences (Covington, 2000). Thus, in order to motivate an individual, it is important to meet external factors in the first place (Kurt, 2005). When considered in this context, it might be deemed that high external motivation of teachers is positive for their general motivation. In their research, Uçar and Dağlı (2017) also found that the participant teachers' external motivation levels were higher. Another study concluded that the teachers were motivated by external factors the most (Ada, Akan, Ayık, Yıldırım \& Yalçın, 2013). Similarly, in a survey on public employees, it was determined that the employees were more motivated when provided with financial awards, work appreciation and promotion opportunities and when noticed with personal ideas (Öztürk \& Dündar, 2003). On the contrary, in a study conducted by Ertürk (2016), the participant teachers scored external motivation higher than their internal motivation.

In the study, it was seen that the external motivation perceptions of the female teachers were higher than those of the male teachers. This might be interpreted as follows: external motivation tools have a more important role in motivating female teachers and they are more influenced by external motivation tools such as rewards, appreciation, salary bonus, etc. when compared to male teachers. The finding is parallel with some research results in the literature (Alemdağ, Öncü \& Yılmaz, 2014; Polat, 2010; Uçar, 2015). In a research with primary school teachers, the motivation perceptions of the female teachers were found higher than those of the male teachers in the following sub-dimensions: positive attitude towards profession, appreciation of professional success and professional happiness (Argon, İsmetoğlu \& İşeri, 2014). On the other hand, in some studies (Argon \& Ertürk, 2013; Recepoğlu, 2012), it was concluded that motivation of teachers did not significantly vary according to gender.

According to the findings of the research, the teachers' motivation perceptions did not show any significant difference according to professional seniority. In the literature, there are different research results about the effect of professional seniority on teacher motivation. For example, Çevik and Köse (2017) found in their study that the teachers' motivation did not significantly vary according to professional seniority. Ertürk (2016) concluded that the motivation of the participant teachers significantly varied according to professional seniority and that as seniority increased, teacher motivation increased as well. In the studies by Recepoğlu (2012) and Uçar (2015), it was concluded that the teachers' motivations varied according to professional seniority and the motivation perceptions of those with 1 to 5 years of teaching experience were higher.

In the study, the teachers' motivation perceptions did not show any significant difference according to marital status and school type. In other words, marital status and school type did not influence the teachers' motivation perceptions at a statistically significant level.

The teachers' motivation perceptions were found to be statistically predicted from their organizational culture perceptions both in the external motivation and internal motivation dimensions. The teachers' perceptions of organizational culture predicted internal motivation more than external motivation. On the other hand, it was found that there was a significant relationship between the teachers' external motivation perceptions and the support dimension of organizational culture in schools. In other words, it was determined that the organizational culture dimension which affected the teachers' external motivation perceptions was support culture. In organizations with a tendency to have support culture, individuals are the focus. Support culture is similar to the human oriented character of organizational culture (Parthasaraty \& Ramalingam, 2015). In support culture, it is essential to develop trust and confidence among employees, concrete support, high expectations for success, honest and open communication, information network development for problem solving and protection of what is important, as well as mutual relationships and commitment between organizational members (Terzi, 2005). The main reason why people are willing to do things in external motivation is that they would like to feel they are valuable to others. This is caused by a sense of belonging or loyalty to a certain group (Ryan \& Deci, 2000). Therefore, support within an organization affects external motivation. In this context, support for teachers, involvement in decision-making process, and creating a culture of trust and cooperation among all employees might provide teachers with external motivation. Similar findings were obtained in a study by Lam, Cheng and Choy (2010). In the study mentioned, it was observed that the perceived school support predicted teacher motivation both directly and indirectly. On the other hand, Özdemir (2012), in his research, also found that support culture had a great influence on teachers' morale.

It was found that there was a moderate correlation between the power, role, success and support culture sub-dimensions 
of organizational culture and the teachers' internal motivation in a positive direction. It was determined that the teachers' perceptions of organizational culture explained variance in their perceptions of internal motivation to a significant degree. It was also seen that the organizational culture dimension which had a great influence on the teachers' internal motivation was success culture. Internal motivation is based on individuals. What is more important is the work itself, not what it provides. Here, the individual motivates himself. Dimensions such as success and responsibility are mostly motivation dimensions associated with components such as job itself, and performance of the doer (Özdaşlı \& Akman, 2012). In internal motivation, activities are carried out for personal satisfaction. In this type of motivation, one acts for his own interests (Ryan \& Deci, 2000). In success culture, individual responsibility is emphasized by prioritizing the execution of workflow and goal attainment rather than rules (Terzi, 2005). In this respect, the influence of success culture on teachers' internal motivation perceptions is comprehensible.

Organizations have their own unique cultural structure. This cultural structure is closely related to many dimensions as well as being directly associated with individuals. These different factors shape organizational culture structure. Organizations seeking success, in this context, need to understand and control organizational culture that explains organizational behavior and the effects of organizational culture on employees. In this context, the following recommendations can be taken into consideration in the light of the above-mentioned results;

- As a result of the research finding that the participant female teachers when compared to the male ones and the married teachers when compared to the single ones thought schools tended to have power culture, female and single teachers might get involved in school related work more.

- As a result of the research, it was concluded that the support culture perceptions of the teachers who worked for 7 years or less had lower perception levels than those of the teachers with 20 years or more experience; therefore, novice teachers may be offered a more supportive environment in schools and be made to feel that they are appreciated.

- Since the participant teachers employed in general high schools were found to have more positive organizational culture perceptions than those employed in vocational and technical high in all the organizational culture dimensions, teachers' school culture perceptions may be improved by arranging activities to establish common values and understandings in vocational and technical high schools.

- As a result of the finding that the external motivation perceptions of the participant female teachers were higher than the male teachers, external stimuli that will motivate male teachers might be included in schools.

- When the influence of success and support culture dimensions of organizational culture on teachers' motivation perceptions is taken into consideration, motivation perceptions of teachers, as crucial part of the education system, might be increased by providing practices in which teachers are supported and enabled to achieve things. In this sense, motivational techniques employed in schools might get integrated with organizational culture.

\section{References}

Ada, Ş., Akan, D., Ayık, A., Yıldırım, İ., \& Yalçın, S. (2013). Motivation factors of teachers. Ataturk University Journal of Graduate School of Social Sciences, 17(3), 151-166.

Aelterman, A., Engels, N, Petegem, K. V., \& Verhaeghe, J. (2007). The wellbeing of teachers Flanders: The importance of a supportive school culture. Educational Studies, 33(3), 285-298. https://doi.org/10.1080/03055690701423085

Alayoğlu, N., \& Doğan, E. A. (2015). Effects of organizational culture on employee motivation: An application in municipal sector, Istanbul Commerce University Foreign Trade Institute, Discussion Texts; http://www.ticaret.edu.tr/uploads/dosyalar/921/WPS\%20NO \%2005\% 202015-08.pdf [25.06.2018].

Alemdağ, C., Öncü, E., \& Yılmaz, A. K. (2014). Pre-service physical education teachers' academic motivation and academic self-efficacy. Hacettepe Journal of Sport Sciences, 25(1), 23-35.

Amabile, T. M. (1997). Motivating creativity in organizations: on doing what you love and loving what you do. California Management Review, 40(1), 39-58. https://doi.org/10.2307/41165921

Argon, T., \& Ertürk, R. (2013). Intrinsic motivations of primary school teachers and their perceptions of organizational identity. Educational Administration: Theory and Practice, 19(2), 159-179.

Argon, T., İsmetoğlu, M., \& İşeri, B. (2014). Artistic supervision at primary schools and teachers' opinions about artistic supervision upon teacher motivation. Journal of Research in Education and Teaching, 3(2), 286 -296.

Atkinson, E. S. (2000). An investigation into the relationship between teacher motivation and pupil motivation. Educational Psychology, 20(1), 45-57. https://doi.org/10.1080/014434100110371 
Ayık, A. (2007). The relationship between the effectiveness of school culture which is created in primary schools (case of Erzurum). Unpublished doctoral dissertation. Atatürk University, Erzurum.

Ayık, A., \& Ada, Ş. (2009). The relationship between the effectiveness of school culture which is created in primary schools. University of Gaziantep Journal of Social Sciences, 8, 429-446.

Ayık, A., \& Şayir, G. (2015). Investigation of the relationship between learning organization and school culture according to perceptions of teachers. Elemantary Education Online, 14(2), 379-394.

Balay, R., Kaya, A., \& Culha, A. (2013). Relationship between organizational culture and organizational cynicism. Cumhuriyet University Journal of Economics and Administrative Sciences, 14(2), 123-144.

Balc1, A. (1996). Effective school and applicability in Turkey. New Turkey, 7, 126-139.

Başaran, İ. E. (2004). Human relations in management. Ankara: Nobel Publishing

Budak, S. (2005). Dictionary of psychology. Ankara: Bilim ve Sanat Publishing.

Bursalığlu, Z. (2000). New structure and behavior in school management. Ankara: Pegem Publishing

Can, A. (2014). Quantitative data analysis in the process of scientific research with SPSS. Ankara: Pegem Publishing

Can, N. (2013). Teacher leadership. Ankara: Pegem Publishing.

Carey, K. (2004). The real value of teachers. The Education Trust, 8(1), 3-43.

Çelik, M. (2007). Organizational culture and organizational citizenship behavior. Unpublished doctoral dissertation, Atatürk University, Erzurum.

Çetin, M., Doğan, B., \& Kınık, Ş. F. (2016). The impact of organizational culture on the decision-making styles of the undergraduate students in higher education. The Journal of International Education Science, 3(9), 223-232.

Çevik, A., \& Köse, A. (2017). An investigation about the relationship between teachers' perception on school cultures and their motivations. Journal of the Human and Social Sciences Researches, 6(2), 996-1014.

Chişiu, C. M. (2013). The role of motivation in school evaluation: Teachers and students-partners in the assessment process. Revista Romaneasca Pentru Educatie Multidimesnionala, 5(2), 119-129. https://doi.org/10.18662/rrem/2013.0502.10

Covington, M. V. (2000). Intrinsic versus extrinsic motivation in schools: a reconciliation. Current Directıons in Psychological Sclence, 9(1), 22-25. https://doi.org/10.1111/1467-8721.00052

Cüceloğlu, D. (1999). Human and behavior. İstanbul: Remzi Publishing.

Deal, T. E., \& Peterson, K. D. (1990). The principal role of shaping culture. Washington: Office of Educational Research and İmprovement.

Demirtaş, Z. (2010). The relationship between school culture and student achievement. Education and Science, 35(158), 3-13.

Doğan, S. (2017). School Culture and Climate. C.T. Uğurlu (Ed) in School Management (s.91-126). Ankara: Anı Publishing.

Doğan, V., \& Yllmaz, C. (2017). Determination of suppression effect and comparison of independent variable's relative importance in management sciences and marketing. International Journal of Management Economics and Business, 13(2), 385-406. https://doi.org/10.17130/ijmeb.2017228690

Ertürk R. (2016). Work motivation of teachers. Journal of Education, Theory and Practical Research, 2(3), 1-15.

Frrat, N. (2007). School culture and teachers' value system. Unpublished master's thesis. Dokuz Eylül University, İzmir.

Gligorovic, B., Nikolic, M., Terek, E., Glusac, D., \& Tasıc, I. (2016). The impact school culture on Serbian primary teachers' job satisfaction. Hacettepe University Journal of Education, 31(2), 231-248. https://doi.org/10.16986/HUJE.2016015184

Han, J., \&Yin, H. (2016). Teacher motivation: definition, research development and implications for teachers. Teacher Education \& Development, 3, 1-18. https://doi.org/10.1080/2331186X.2016.1217819

Handy, C. B. (1981). Understanding organizations (2nd Ed.). Great Britain: Hazell Watson \& Viney Ltd.

Harrison, R. (1975). Diagnosing organizational ideology. Annual handbook for group facilators. J.E. Jones and J.W. Pfeffer (Ed). University Associates Inc. In Handy, C. B. (1981): Understanding organizations. 2nd edition, Hazell Watson \& Viney Ltd. Great Britain. 
Hattie, J. (2013). Teachers make a difference what is the research evidence? Professional Learning and Leadership Development, 1-17.

Haycock, K. (1998). Good teaching matters: How well-qualified teachers can close the gap. The Education Trust, 1-31. https://doi.org/10.1093/maghis/13.1.61

Hofstede, G. (1980). Culture consequences: International differences in work related values. London: Sage.

Hoy, W. K., \& Miskel, C. G. (2010). Educational management theory, research and application, (S. Turan, Transl. Ed.) Ankara: Nobel Publishing.

İpek, C. (1999). Organizational culture and teacher-student relationship in public and private secondary schools. Unpublished doctoral dissertation, Ankara University, Ankara.

İpek, C. (2012). Secondary school teachers' perceptions about organizational culture and organizational citizenship behavior. Educational Administration: Theory and Practice, 18(3), 399-434.

Irmak, O. (2017). Anatolian high schools teachers' perception of school culture the case of Malatya province Battalgazi district. Unpublished master's thesis. Yıldız Teknik University, İstanbul.

Jesus, S. N., \& Lens, W. (2005). An integrated model for the study of teacher motivation. Applied Psychology: An International Review, 54(1), 119-134. https://doi.org/10.1111/j.1464-0597.2005.00199.x

Karaoğlu, Z. (2014). The relationship between organizational culture and employee motivation: an empirical study on five star chain hotels in İstanbul. Unpublished master's thesis, İstanbul University, İstanbul.

Kasenga, F., \& Hurtig, A. K. (2014). Staff motivation and welfare in Adventist health facilities in Malawi: A qualitative study. BMC Health Services Research, 14(486). https://doi.org/10.1186/s12913-014-0486-4

Kavi, E. (2011). The effect of organizational culture on the motivation level with double-s model: Comparative research in banking and private finance institutions, Journal of Social Politics Conferences, 54, 117-137, http://dergipark.gov.tr/download/article-file/9304 [25.06.2018].

Kurt, T. (2005). Analysis of Herzberg's two factors motivation theory on teacher motivaton. Gazi University Journal of Gazi Educational Faculty, 25(1), 285-299.

Lam, S. F., Cheng, R. W. I., \& Choy, H. C. (2010). School support and teacher motivation to implement project-based learning. Learning and Instruction, 20(6), 487-497. https://doi.org/10.1016/j.learninstruc.2009.07.003

Morgan, G. (1998). Metaphor in management and organizational theories (G. Bulut, transl.), İstanbul: MESS Publication.

Mottaz, C. J. (1985). The relative importance of intrinsic and extrinsic rewards as determinants of work satisfaction. Sociological Quarterly, 26(3), 365-385. https://doi.org/10.1111/j.1533-8525.1985.tb00233.x

Murat, G., \& Açıkgöz, B. (2007). An analysis of the managers' perceptions about organizational culture: the case of Zonguldak Karaelmas University. Zonguldak Karaelmas University Social Sciences Journal, 3(5), 1-20.

Owens, R. G. (1987). Organizational behavior in education, New Jersey: Prentice-Hall.

Özdaşl1, K., \& Akman, H. (2012). The diversification of gender and organizational statute in internal and external motivations: the research on the engıneers and the technicians in Türk Telekomünikasyon A.Ş. Süleyman Demirel Üniversity Visionary E-Journal, 4(7), 73-81.

Özdemir, A. (2006). The expected and observed behaviors of school principles to form a school culture and presenting it to the public. Journal of Turkish Educational Sciences, 4(4), 411-433.

Özdemir, S. (2012). The relationship between school culture and organizational health in primary schools. Educational Administration: Theory and Practice, 18(4), 599-620.

Özdere, M. (2018). An analysis of the relationship between organizational culture and organizational justice. Journal of Social and Humanities Sciences Research, 5(19), 681-689. https://doi.org/10.26450/jshsr.405

Öztürk, Z., \& Dündar, H. (2003), Organizational motivation and the factors which motivate the public workers. C.Ü. Journal of Economics and Administrative Sciences, 4(2), 57-67.

Parthasarathy, K., \& Ramalingam, S. (2015). An empirıcal study on organization culture and its impact on employee motivation with reference to industrial estates in Chennal. IJABER, 13(19), 287-294.

Pheysey, D. C. (1993). Organizational cultures: Types and transformations. London: Routledge. https://doi.org/10.4324/9780203308851 
Polat, S. (2010). The relationship between administrative powers sources that preschool administrators use and teacher motivation. Unpublished master's thesis. Yeditepe University, İstanbul.

Ramlall, S. (2004). A review of employee motivation theories and their implications for employee retention within organizations. Journal of American Academy of Business, 52-63.

Recepoğlu, E. (2012). Analyzing job motivation of teachers in terms of different variables. Kastamonu Education Journal, 21(2), 575-588.

Remijan, K. W. (2014). Improving teacher motivation in secondary schools with hybrid positions. American Secondary Education, 42(3), 30-38.

Robbins, S. P. (1994). Essential of organizational behavior (S. A. Öztürk, transl.), Eskişehir: Etam A. Ş. Publishing.

Ryan, R. M., \& Deci, E. L. (2000). Intrinsic and extrinsic motivations: classic definitions and new directions. Contemporary Educational Psychology, 25, 54-67. https://doi.org/10.1006/ceps.1999.1020

Saban, A. (2002). The process of learning teaching new theories and approaches. Ankara: Nobel Publishing.

Sabancı, A., Şahin, A., Sönmez, M. A., \&Yılmaz, O. (2017). Views of School Managers and Teachers about School Culture, E-International Journal of Educational Research, 8(1), 28-45. https://doi.org/10.19160/5000186332.

Şahin, M. (2017). Investigation of the relationship between teachers' perceptions of their efficacy levels and school culture. Unpublished master's thesis. İstanbul Sabahattin Zaim University-Marmara University, İstanbul.

Şahin, S. (2011). The relationship between instructional leadership and school culture (İzmir province example). Educational Sciences: Theory and Practice, 11, 1909-1928.

Schein, E. H. (1984). Coming to a new awareness of organizational culture. Sloan Management Review, 25(2), 3-16.

Schoen, L. T., \& Teddlie, C. (2008). A new model of school culture: a response to a call for conceptual clarity, School Effectiveness and School Improvement, 19(2), 129-153. https://doi.org/10.1080/09243450802095278

Schoen, L. T., \& Tedlie, C. (2008). A new model of school culture: a response to a call for conceptual clarity. School Effectiveness and School Improvement, 19(2), 129-153. https://doi.org/10.1080/09243450802095278

Senge, P., Cambron-McCabe, N., Lucas, T., Smith, B. Dutton, J., \& Kleiner, A. (2014). Learning schools, (M. Çetin, transl.). Ankara: Nobel Publishing.

Sergiovanni, T. J. (1984). Leadership and excellence in schooling. Educational Leadership, 41(5), 4-13.

Sertel, G. (2016). The effect of organizational culture on teachers' motivation in schools (Honaz district sample in Denizli province). Unpublished master's project, Pamukkale University, Denizli.

Şimşek, A., \& Babaoğlan, E. (2015). School administrators' opinion about organizational culture. Elementary Education Online, 14(4), 1222-1240. https://doi.org/10.17051/io.2015.11521

Şimşek, H. (2010). The role of teacher in the education system and the teaching profession. H.B. Memduhoğlu and K. Y1lmaz (Ed), in Introduction to education science (pp.241-265), Ankara: Pegem Publishing.

Sokro, E. (2012). Analysis of the relationship that exists between organizational culture, motıvation and performance. Problems of Management in the 21. Century, 3, 106-119.

Sop, S. (2016). The impact of organization culture on employee motivation: Example of Celal Bayar University. Unpublished master's thesis, Turkish Aeronautical Association University, Ankara.

Sözer, Z. (2006). The relationship between organizational culture and employee motivation. Unpublished master's thesis, Yıldız Teknik University, İstanbul.

Steers, R. M., Porter, L. W., \& Bigley, G. A. (1996). Motivation and Leadership at Work. Singapore: McGraww Hill Companies.

Stolp, S., \& Smith, S. (1995). Transforming school culture: Stories, symbols, values and the leader's role. ERIC Clearinghouse on Education Management, USA: University of Oregon

Tabachnick, B. G., \& Fidell, L. S. (2013). Using multivariate statistics. Boston: Pearson.

Tanriöğen, Z. M., Baştürk, R., \& Başer, M. U. (2014). Bolman and Deal's four frame theory: Manager's leadership style and organizational culture. Pamukkale University Journal of Education, 36(2), 191-202.

Terzi, A. R. (2005). Organizational culture in primary schools. Educational Administration: Theory and Practice, 43, 423-442. 
Thahier, R., Ridjal, S., \& Risani, F. (2014). The influence of leadership style and motivation upon employee performance in the provincial secretary office of West Sulawesi. Social Sciences and Humanities, 6(1), 116-124. https://doi.org/10.7813/2075-4124.2014/6-1/B.17

Turan, S., \& Bektas, F. (2013). The relationship between school culture and leadership practices. Eurasian Journal of Educational Research, 52, 155-168.

Uçar, R. (2015). Relationship between distributed leadership behavior of primary school principals and teachers' levels of motivation and creativity. Unpublished doctoral dissertation. Dicle University, Diyarbakır.

Uçar, R., \& Dağl1, A. (2017). Relationship between distributed leadership behavior of primary school principals and teachers' levels of motivation and creativity. Electronic Journal of Social Sciences, 16(60), 198-216.

Viseu, J., Jesus, J. N., Rus, C., Canavarro, J. M., \& Pereira, J. (2016). Relationship between teacher motivation and organizational variables: a literature review. Paideia, 26(63), 111-120. https://doi.org/10.1590/1982-43272663201613

Vislocky, K. L. (2005). The relationship between school culture and student achievement in middle schools, Unpublished Doctoral Dissertation, Florida: University of Central Florida.

Wu, S. M. (2012). Relationships among perceived likeability of principal, school identity, and teacher motivation. Comprehensive Psychology, 1(6), 1-7. https://doi.org/10.2466/01.11.21.CP.1.6

Wu, S. M. (2015). Development and application of the measures of school value, teacher autonomy, and teacher motivation, The New Educational Review, 240-250.

$\mathrm{Wu}, \mathrm{X}$. (2003). Intrinsic motivation and young language learners: the impact of the classroom environment. System, 31, 501-517. https://doi.org/10.1016/j.system.2003.04.001

Yaprak, K. Ö. (2015). Corelation between organizational culture and organizational citizenship behavior (Ballkesir central district sample. Unpublished master's thesis, Balıkesir University, Balıkesir.

Yazıc1, H. (2009). Teaching profession sources of motivation and basic attitudes: a theoretical overview. Kastamonu Education Journal, 17(1), 33-46.

Yenihan, B. (2015). The effect of organization culture on the motivation: a qualitative study on the university students, Hak-İs International Journal of Labour and Society, 4(10), 170-183.

Yılmaz, E., Viseu, J., Jesus, J. N., Rus, C., Canavarro, J. M., \& Pereira, J. (2016). Relationship between teacher motivation and organizational variables: a literature review. In Kurşun, A. (2015). The relationship between school culture and academic optimism. Mehmet Akif Ersoy University Journal of education Faculty, 1(35), 46-69.

Yılmaz, F. (2009). Effects of organizational culture in educational organizations on teachers' job motivation. Unpublished Master's thesis, Selçuk University, Konya.

Yusof, H., Osman, M. N. A. H., Viseu, J., Jesus, J.N., Rus, C., Canavarro, J. M., \& Pereira, J. (2016). Relationship between teacher motivation and organizational variables: a literature review. In Noor, M. A. M. (2016). School culture and its relationship with teacher leadership. International Journal of Academic Research in Business and Social Sciences, 6(11), 272-286. https://doi.org/10.6007/IJARBSS/v6-i11/2396

\section{Copyrights}

Copyright for this article is retained by the author(s), with first publication rights granted to the journal.

This is an open-access article distributed under the terms and conditions of the Creative Commons Attribution license which permits unrestricted use, distribution, and reproduction in any medium, provided the original work is properly cited. 